\title{
Front Matter: Volume 11309
}

, "Front Matter: Volume 11309," Proc. SPIE 11309, Next-Generation Optical Communication: Components, Sub-Systems, and Systems IX, 1130901 (20 February 2020); doi: 10.1117/12.2566754

SPIE. Event: SPIE OPTO, 2020, San Francisco, California, United States 


\title{
PROCEEDINGS OF SPIE
}

\section{Next-Generation Optical Communication: Components, Sub-Systems, and Systems IX}

\author{
Guifang Li \\ Xiang Zhou \\ Editors
}

5-6 February 2020

San Francisco, California, United States

Sponsored by

SPIE

Cosponsored by

Corning Incorporated (United States)

NTT Electronics (Japan)

Published by

SPIE

Volume 11309 
The papers in this volume were part of the technical conference cited on the cover and title page. Papers were selected and subject to review by the editors and conference program committee. Some conference presentations may not be available for publication. Additional papers and presentation recordings may be available online in the SPIE Digital Library at SPIEDigitalLibrary.org.

The papers reflect the work and thoughts of the authors and are published herein as submitted. The publisher is not responsible for the validity of the information or for any outcomes resulting from reliance thereon.

Please use the following format to cite material from these proceedings:

Author(s), "Title of Paper," in Next-Generation Optical Communication: Components, Sub-Systems, and Systems IX, edited by Guifang Li, Xiang Zhou, Proceedings of SPIE Vol. 11309 (SPIE, Bellingham, WA, 2020) Seven-digit Article CID Number.

ISSN: 0277-786X

ISSN: 1996-756X (electronic)

ISBN: 9781510633810

ISBN: 9781510633827 (electronic)

Published by

SPIE

P.O. Box 10, Bellingham, Washington 98227-0010 USA

Telephone +1 3606763290 (Pacific Time) · Fax +1 3606471445

SPIE.org

Copyright (c) 2020, Society of Photo-Optical Instrumentation Engineers.

Copying of material in this book for internal or personal use, or for the internal or personal use of specific clients, beyond the fair use provisions granted by the U.S. Copyright Law is authorized by SPIE subject to payment of copying fees. The Transactional Reporting Service base fee for this volume is $\$ 21.00$ per article (or portion thereof), which should be paid directly to the Copyright Clearance Center (CCC), 222 Rosewood Drive, Danvers, MA 01923. Payment may also be made electronically through CCC Online at copyright.com. Other copying for republication, resale, advertising or promotion, or any form of systematic or multiple reproduction of any material in this book is prohibited except with permission in writing from the publisher. The CCC fee code is $0277-$ $786 \times / 20 / \$ 21.00$.

Printed in the United States of America by Curran Associates, Inc., under license from SPIE.

Publication of record for individual papers is online in the SPIE Digital Library.

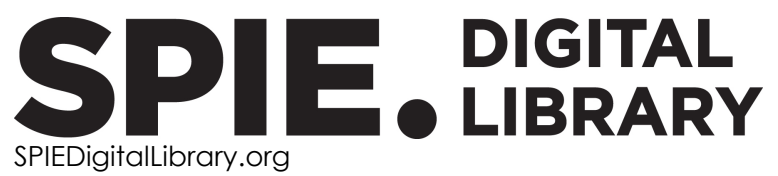

Paper Numbering: Proceedings of SPIE follow an e-First publication model. A unique citation identifier (CID) number is assigned to each article at the time of publication. Utilization of CIDs allows articles to be fully citable as soon as they are published online, and connects the same identifier to all online and print versions of the publication. SPIE uses a seven-digit CID article numbering system structured as follows:

- The first five digits correspond to the SPIE volume number.

- The last two digits indicate publication order within the volume using a Base 36 numbering system employing both numerals and letters. These two-number sets start with $00,01,02,03,04$, 05, 06, 07, 08, 09, 0A, OB ... 0Z, followed by 10-1Z, 20-2Z, etc. The CID Number appears on each page of the manuscript. 


\title{
Contents
}

\author{
$\checkmark \quad$ Authors \\ vii Conference Committee
}

$\begin{array}{ll}\text { SESSION } 1 & \begin{array}{l}\text { OPTICAL COMMUNICATIONS: JOINT KEYNOTE SESSION WITH CONFERENCES 11307, 11308, AND } \\ 11309\end{array}\end{array}$

1130902 Recent breakthroughs in hollow core fiber technology (Keynote Paper) [1 1309-1]

SESSION 2 SDM

1130904 Collective measurement of DMD in 6-mode 19-core fiber using low-coherence digital holography [11309-3]

1130906 Optimizing quasi-adiabaticity and its application in photonic lantern devices [11309-5]

1130908 Mode-selective switch for ROADM using volume holograms and spatial light modulator [11309-7]

1130909 Spatial mode exchange technique using volume holograms with a random optical diffuser to reduce modal cross-talks [11309-8]

\section{SESSION $3 \quad$ FIBERS AND DEVICES}

11309 OA DCl systems with ultra-low loss and low dispersion fiber (Invited Paper) [1 1309-9]

11309 OC Integrated Nyquist transmitter for data rates up to 100 Gbps [11309-11]

11309 OE Joint-compensation of silicon photonics modulator in short reach coherent networks [11309-13]

11309 OF Integrated-optic spectrum synthesis circuit for manipulating 64 frequency components [11309-15]

\section{SESSION $4 \quad$ TRANSMISSION SYSTEMS}

11309 Ol Beyond 100-Tb/s ultra-wideband transmission in S, C, and L bands over single-mode fiber (Invited Paper) [1 1309-18] 
11309 OK Frequency offset estimation algorithm for a multi-subcarrier coherent fiber optical system [1 1309-20]

$11309 \mathrm{OL} \quad$ Applications of machine-learning in optical communications and networks (Invited Paper) [11309-21]

$1130900 \quad$ Trajectory redesign within a complex intersection for VLC ready connected cars [11309-24]

\section{POSTER SESSION}

11309 OP Optimization of waveguide photodetector with thin absorbing layer and large responsivity [1 1309-25]

$113090 Q \quad$ Next-generation millimeter-wave-over-fiber network based on FBMC with optical heterodyning technique [11309-26]

11309 OS Comparison of twin-SSB modulation schemes [11309-28] 


\section{Authors}

Numbers in the index correspond to the last two digits of the seven-digit citation identifier (CID) article numbering system used in Proceedings of SPIE. The first five digits reflect the volume number. Base 36 numbering is employed for the last two digits and indicates the order of articles within the volume. Numbers start with 00, 01, 02, 03, 04, 05, 06, 07, 08, 09, OA, OB...0Z, followed by 10-1Z, 20-2Z, etc.

Abdo, Ahmad, OE

Abe, Yuta, 04

Ben-Hamida, Naim, OE

Bradley, Thomas, 02

Chen, Yong, 02

Choe, J.S., OP

D'Amours, Claude, OE

Davidson, Ian A., 02

Dong, Hao, OA

Downie, John D., OA, OK

Fan, Qirui, OL

Goto, Yuta, 08, 09

Hamaoka, Fukutaro, 0

Han, W.S., OP

Hayashi, Hotaka, 08, 09

Hayes, John R., 02

Himmelreich, James E., OA

Horikoshi, Kengo, 0 I

Hurley, Jason E., OA

Jasion, Gregory T., 02

Khan, Faisal Nadeem, OL

Kim, D. J., OP

Kim, J. H., OP

Kisaka, Yoshiaki, 0 I

Kumar, Shiva, OK

Lau, Alan Pak Tao, OL

Li, Ming-Jun, OA

Liang, Xiaojun, OA, OK

Louro, P., 00

Lu, Chao, OL

Maeda, Tomohiro, 08

Makovejs, Sergejs, OA

Mandal, Gour Chandra, OQ

Matsushita, Asuka, ol

Minoguchi, Kyo, Ol

Mulvad, Hans Christian, 02

Nakagawa, Ryoto, OS

Nakamura, Masanori, ol

Nakamura, Moriya, OS

Numkam Fokoua, Eric, 02

Ogawa, Kazuhisa, 04, 08, 09

Okamoto, Atsushi, 04, 08, 09

Okamoto, Seiji, OI

Parvizi, Mahdi, OE

Poletti, Francesco, 02

Preussler, Stefan, $0 \mathrm{C}$

Ramdial, Ryan, OK

Rhee, Hanjo, OC

Richardson, David J., 02
Sakr, Hesham, 02

Sasai, Takeo, 01

Schneider, Thomas, OC

Sharma, Anurag, 06

Shiba, Taijun, 08, 09

Shinada, Satoshi, 08, 09

Soma, Daiki, 04

Su, Hui, OA

Sunder, Sugeet, 06

Takahata, Taketoshi, 08, 09

Takanashi, Yuya, OS

Takiguchi, Koichi, OF

Taranta, Austin, 02

Tomita, Akihisa, 04, 08, 09

Tsuritani, Takehiro, 04

Vieira, M. A., 00

Vieira, M., 00

Vieira, P., 00

Wada, Naoya, 08, 09

Wakayama, Yuta, 04

Wang, Wei, 02

Wheeler, Natalie V., 02

Wood, William A., OK

Yamazaki, Ełsushi, OI

Zhang, Shuanglu, 09 
Proc. of SPIE Vol. 11309 1130901-6 Downloaded From: https://www.spiedigitallibrary.org/conference-proceedings-of-spie on 26 Apr 2023
Terms of Use: https://www.spiedigitallibrary.org/terms-of-use 


\section{Conference Committee}

Symposium Chairs

Sailing He, KTH Royal Institute of Technology (Sweden) and Zhejiang University (China)

Yasuhiro Koike, Keio University (Japan)

Symposium Co-chairs

Connie J. Chang-Hasnain, University of California, Berkeley (United States)

Graham T. Reed, Optoelectronics Research Centre, University of Southampton (United Kingdom)

Program Track Chair

Benjamin B. Dingle, Nasfine Photonics, Inc. (United States)

Conference Chairs

Guifang Li, CREOL, The College of Optics and Photonics, University of Central Florida (United States)

Xiang Zhou, Google (United States)

Conference Program Committee

Kazi S. Abedin, OFS Fitel LLC (United States)

Jin-Xing Cai, TE Connectivity Ltd. (United States)

Hwan Seok Chung, Electronics and Telecommunications Research Institute (Korea, Republic of)

Benjamin B. Dingel, Nasfine Photonics, Inc. (United States)

Ezra Ip, NEC Labs. America, Inc. (United States)

Yongmin Jung, Optoelectronics Research Centre, University of Southampton (United Kingdom)

Inuk Kang, LGS Innovations, LLC (United States)

Tsuyoshi Konishi, Osaka University (Japan)

Ming-Jun Li, Corning Incorporated (United States)

Chao Lu, The Hong Kong Polytechnic University (Hong Kong, China)

Akihiro Maruta, Osaka University (Japan)

Takashi Sasaki, Innovation Core SEI, Inc. (United States)

Siyuan Yu, University of Bristol (United Kingdom)

Yanjun Zhu, FutureWei Technologies, Inc. (United States) 


\section{Session Chairs}

1 Optical Communications: Joint Keynote Session with Conferences

11307, 11308, and 11309

Spiros Mikroulis, Huawei Technologies Company, Ltd. (Germany)

Guifang Li, CREOL, The College of Optics and Photonics, University of Central Florida (United States)

2 SDM

Xiang Zhou, Google (United States)

Guifang Li, CREOL, The College of Optics and Photonics, University of Central Florida (United States)

3 Fibers and Devices

Oleg Sinkin, SubCom, LLC, (United States)

4 Transmission Systems

Jian Fang, NEC Labs. America, Inc. (United States) 